\title{
Implementasi Pendidikan Karakter Dalam Pembelajaran Bahasa Indonesia di Sekolah Dasar
}

\author{
Kadek Hengki Primayana \\ Sekolah Tinggi Agama Hindu Negeri Mpu Kuturan Singaraja, Indonesia \\ hengkiprimayana@stahnmpukuturan.ac.id
}

\begin{abstract}
This study describes the implementation of character education in Indonesian language learning, including planning, implementation, and assessment. This research is descriptive research with a qualitative approach. The results obtained in this study are that character education in learning Indonesian content at SDN 2 Tukadmungga has been carried out both in planning, implementing, and assessing learning but not all of it has been implemented because it is still in the covid-19 pandemic. At the learning planning stage, the teacher has entered the character values that will be applied in learning in the syllabus and lesson plans. The implementation of learning Indonesian content at SDN 2 Tukadmunga is enough to be carried out through online learning via WhatsApp. Assessment of Indonesian language content learning includes effective assessment.
\end{abstract}

\section{Keywords: Character building; Learning; Indonesian; Primary school}

\begin{abstract}
Abstrak
Penelitian ini mendeskripsikan implementasi pendidikan karakter dalam pembelajaran muatan bahasa Indonesia, meliputi perencanaan, pelaksanaan, dan penilaian. Penelitian ini merupakan penelitian deskriptif dengan pendekatan kualitatif. Hasil yang diperoleh dalam penelitian ini adalah pendidikan karakter dalam pembelajaran muatan bahasa Indonesia di SDN 2 Tukadmungga sudah dilaksanakan dengan baik dalam perencanaan, pelaksanaan, dan penilaian pembelajaran namun belum semuanya terlaksana karena masih dalam masa pandemi covid-19. Pada tahap perencanaan pembelajaran, guru sudah memasukkan nilai-nilai karakter yang akan diterapkan dalam pembelajaran dalam silabus dan RPP. Pelaksanaan pembelajaran muatan bahasa Indonesia di SDN 2 Tukadmunga sudah cukup dilaksanakan melalui pembelajaran online melalui WhatsApp. Penilaian pembelajaran muatan bahasa Indonesia termasuk penilaian yang efektif.
\end{abstract}

\section{Kata Kunci: Pendidikan Karakter; Pembelajaran; Bahasa Indonesia; Sekolah Dasar}

\section{Pendahuluan}

Menghadapi berbagai tantangan sistem pendidikan nasional abad 21, secara tegas mempersiapkan masa depan bangsa yang berkualitas dan berdaya saing. Salah satu hal yang paling kritis di abad 21 adalah penguatan pendidikan karakter dan menghadapi era revolusi industri 4.0 (Silfia, 2018). Pembangunan karakter bangsa merupakan titik fokus paling krusial yang tidak bisa dipisahkan dari pembangunan nasional (Akhir, 2017). Undang-undang Nomor 17 Tahun 2007 tentang 2 Rencana Pembangunan Jangka Panjang Nasional Tahun 2005-2025 tentang pembangunan karakter bangsa dalam kebijakan nasional dirumuskan untuk melaksanakan amanat tersebut. Dari delapan misi yang mewujudkan visi pembangunan Nasional, misi pertama adalah membangun karakter bangsa (Bappenas, 2004). Tercapainya pembangunan karakter bangsa ditandai dengan 
terbentuknya bangsa yang tangguh, berbudi luhur, berdaya saing, toleran, kooperatif, enerjik, beretika, terdidik, patriotik, dan berwawasan Iptek Pancasila, diisi dengan iman dan takwa kepada Tuhan Yang Maha Esa. Membangun karakter bangsa tertuang dalam kebijakan Nasional Permendikbud Nomor 54 Tahun 2013 tentang kompetensi lulusan harus memiliki sikap, keterampilan, dan pengetahuan. Aspek sikap merupakan aspek yang berkaitan dengan karakter siswa.

Perilaku yang mencerminkan perbuatan orang yang berakhlak mulia, beriman, berilmu, amanah, dan bertanggung jawab dalam interaksi afektif dengan pergaulan dan lingkungan sosial dan alam dalam ruang lingkup keberadaannya. Peraturan Pemerintah Nomor 19 Tahun 2005 tentang Standar Nasional Pendidikan Pasal 7 Nomor 2, adalah penyelenggaraan pendidikan kepribadian atau budi pekerti yang diatur dalam penyelenggaraan pendidikan pada semua jenjang melalui muatan atau kegiatan budi pekerti luhur, Agama, bahasa, kewarganegaraan, pendidikan jasmani, dan seni budaya. Mendiknas menjelaskan bahwa salah satu cara untuk mengembangkan kepribadian atau karakter adalah melalui bahasa.

Di sekolah dasar, muatan materi bahasa Indonesia secara fungsional ditujukan untuk menjadikan bahasa Indonesia sebagai bahasa yang profesional dan ilmiah. Menurut Keputusan Menteri Pendidikan Nasional Republik Indonesia Nomor 232/U/2000, terdapat pedoman penyusunan silabus untuk tiga perguruan tinggi dan silabus inti untuk pendidikan tinggi dan penilaian prestasi belajar untuk siswa. Di sekolah dasar, pelaksanaan pendidikan bahasa Indonesia masih belum membaik. Pencapaian pembelajar bahasa erat kaitannya dengan kemauan. Belajar bahasa bukan hanya sekedar menghafal, mencipta, membaca, atau mendengarkan, tetapi kepentingannya lebih dari sekedar harapan untuk menggapai masa depan.

Pada saat yang sama, guru berharap agar setiap siswa mencapai kompetensi lulusan dalam hal pengetahuan, keterampilan, terutama sikap atau karakter. Pencapaian siswa tersebut tergantung pada kemampuan guru yang profesional, apresiasi guru terhadap siswa untuk menciptakan perilaku siswa yang berkarakter. Banyak penyimpangan yang dilakukan oleh generasi bangsa Indonesia, mulai dari tingkat sekolah hingga perguruan tinggi. Kasus penyimpangan yang sering terjadi pada siswa di sekolah antara lain menyontek saat ujian atau ujian, kenakalan, tawuran, kekerasan, pembunuhan tidak hormat, tidak bertanggung jawab, ketidakjujuran, ketidakpercayaan, pergaulan bebas, menghisap lem, geng motor, bullying, menggunakan narkoba. Narkoba dan minuman keras, membolos, merokok, tidak disiplin. Kasus penyimpangan yang sering terjadi pada mahasiswa seperti konflik, demonstrasi anarkis, seks bebas, penggunaan narkoba, menyontek, merokok, tawuran antar mahasiswa. Salah satu faktor penyebabnya adalah internal diri siswa, yaitu karakter siswa atau siswa yang masih perlu ditumbuhkan dan dikembangkan (Suardi et al., 2018).

Banyaknya kasus perilaku menyimpang menunjukkan bahwa di lingkungan sekolah nilai-nilai karakter harus ditingkatkan. Nilai-nilai karakter yang ditanamkan diharapkan dapat membangun sikap peserta didik yang memiliki karakter baik dalam kehidupan sekolah, keluarga, dan masyarakat. Pengamatan peneliti terhadap perilaku siswa selama proses pembelajaran berkaitan dengan aspek negatif dari sikap siswa, seperti tidak mengumpulkan tugas tepat waktu, terlambat masuk kelas, membuat keributan saat pembelajaran, mencontek dan tidak membaca petunjuk lembar kerja dengan benar saat pembelajaran. Kegiatan mereka berada di luar instruksi praktis. Jika keadaan ini tidak segera diatasi, akan timbul akibat serius karena penyimpangan karakter. Namun, mereka dapat berimplikasi pada sistem sekolah dan berdampak negatif pada input, proses, dan output pembelajaran (Suardi et al., 2018).

Selain itu juga dapat berdampak pada (a) erosi karakter, erosi perilaku baik dan erosi perilaku positif, (b) persatuan dan solidaritas (rendahnya frekuensi tawuran dan 
pelanggaran hukum), (c) banyak anak yang hanya sukses di bidang kognitif. Sehingga (d) daya saing negara berkurang. Mengatasi hal tersebut membutuhkan pendidikan karakter (Suardi et al., 2018). Tujuannya adalah untuk mengembangkan karakter siswa melalui semua jenjang pendidikan, baik di pendidikan sekolah maupun di pendidikan tinggi.

Pendidikan karakter di sekolah dapat dilakukan melalui proses pembelajaran pada setiap mata pelajaran yang diajarkan oleh guru (Kanji et al., 2019), lebih khusus pendidikan karakter dalam pembelajaran bahasa Indonesia. Karakter yang dapat dikembangkan antara lain karakter disiplin dan tanggung jawab (Akhir, 2018), karakter jujur, karakter bertanggung jawab, karakter percaya diri, karakter santun, karakter kerja keras, karakter kreatif, karakter mandiri, karakter teliti dan karakter hati-hati. Dalam pembelajaran muatan bahasa Indonesia di sekolah dasar, konsep pendidikan karakter merupakan satu kesatuan dalam setiap aspek pembelajaran, mulai dari perencanaan dan pelaksanaan hingga evaluasi.

\section{Metode}

Jenis yang digunakan dalam penelitian ini adalah deskriptif kualitatif. Penelitian ini mendeskripsikan implementasi pendidikan karakter dalam pembelajaran dengan muatan bahasa Indonesia pada siswa sekolah dasar kelas V SDN 2 Tukadmungga. Pemilihan Informan dalam penelitian ini dengan mempertimbangkan pengetahuan atau pemahaman mendalam informan terhadap obyek yang dikaji, yang ditentukan secara purposive sampling. Selain itu memiliki sifat keterbukaan serta obyektif dalam mengungkapkan setiap fenomena yang berkaitan dengan penelitian. Informan yang dipilih adalah informan yang berasal dari guru SDN 2 Tukadmungga yang memiliki relevansi dengan obyek kajian penelitian ini. Penelitian ini meliputi mekanisme perencanaan, pelaksanaan, dan penilaian pembelajaran muatan materi bahasa Indonesia di kelas V SDN 2 Tukadmungga.

\section{Hasil dan Pembahasan}

Hasil penelitian terkait dengan perencanaan, pelaksanaan, penilaian, dan pelaksanaan pendidikan karakter dalam pembelajaran materi bahasa Indonesia di SDN 2 Tukadmungga yang berbasis jaringan (online) melalui media online via WhatsApp hingga pandemi Covid-19. Pembelajaran materi bahasa Indonesia melalui modus online ini telah dilakukan selama masa pandemi Covid-19, termasuk di SDN 2 Tukadmungga.

Pendidikan karakter adalah proses penanaman nilai-nilai kehidupan sehari-hari dalam proses pembelajaran bagi siswa. Pendidikan karakter dalam pembelajaran materi bahasa Indonesia di SDN 2 Tukadmungga dimulai pada tahun 2020. Pendidikan karakter dalam pembelajaran bahasa Indonesia di SDN 2 Tukadmungga dimulai dari guru kelas yang mengajar pembelajaran di kelas V. Guru memiliki peran penting dalam pembinaan.

Guru merencanakan pelaksanaan pengajaran karakter dalam pembelajaran dengan menyusun silabus dan RPP. Rencana pelaksanaan pembelajaran yang digunakan pada masa pandemi Covid-19 adalah lembar rencana pelaksanaan pembelajaran yang selalu disediakan dan dimutakhirkan sebelum mengajar. Guru melaksanakan pembelajaran sesuai dengan minat siswa. Guru menggunakan silabus pembelajaran empat lembar dan RPP dengan nilai-nilai karakter terdaftar. Melalui silabus dan RPP yang dibuat sebelum pembelajaran, guru telah mengimplementasikan rencana pelaksanaan pendidikan karakter.

Guru mencantumkan nilai-nilai karakter yang ingin dicapai dalam RPP dan silabus dalam rencana pelaksanaan pendidikan karakter. Berbeda dengan (Azmi, 2017), tahap perencanaan pendidikan karakter meliputi kegiatan ekstrakurikuler, kegiatan pembudayaan, dan pembiasaan. Guru memilih nilai-nilai karakter yang ingin dicapai melalui pemikiran sekolah yang selaras dengan pemilihan nilai karakter dan visi misi 
sekolah. Nilai karakter harus dicapai dengan mengadaptasi metode, materi, media pembelajaran, dan strategi. Perencanaan pembelajaran nilai karakter yang akan dilakukan sesuai dengan visi dan misi sekolah, peraturan sekolah, media, materi, metode pembelajaran, dan strategi.

Perencanaan pembelajaran dengan menggunakan nilai-nilai karakter yaitu nilai kecerdasan, nilai kejujuran, nilai kepedulian, nilai ketangguhan dan kedisiplinan. Ada empat keterampilan dalam belajar bahasa Indonesia: keterampilan berbicara, keterampilan mendengarkan, keterampilan membaca, dan keterampilan menulis (Akhir, 2017). Dari keempat keterampilan berbahasa Indonesia yang tercantum dalam silabus dan silabus, analisis rencana pelaksanaan pembelajaran yang tampak pada nilai-nilai karakter tidak sama.

Pelaksanaan pendidikan karakter di SDN 2 Tukadmungga dilakukan secara online melalui grup WhatsApp yaitu materi Agama. Melalui budaya sekolah dalam pelaksanaan pendidikan karakter. Kinerja pendidikan karakter sangat dipengaruhi oleh lingkungan budaya sekolah, seperti kedisiplinan saat belajar, yang dilaksanakan mulai pukul 07.15 hingga pukul 12.45. Pelaksanaan pendidikan karakter di SDN 2 Tukadmungga. Melalui contoh guru tepat waktu masuk kelas dipandu melalui kelas whatsapp karena sudah ada pembagian jadwal pembelajaran yang teratur yang sudah diketahui guru. Kegiatan ekstrakurikuluer merupakan bagian dari pengembangan karakter siswa.

Berbeda dengan (Azmi, 2017), tahapan pelaksanaan pendidikan karakter meliputi pelaksanaan kegiatan ekstrakurikuler, kegiatan pembudayaan, dan pelaksanaan pembiasaan. Sedangkan (Saputri, 2013), kinerja pendidikan karakter dilakukan dengan mengintegrasikan nilai-nilai pendidikan karakter dalam pembelajaran. Kegiatan ekstrakurikuler ini mengintegrasikan nilai-nilai karakter dan pembiasaan melalui penciptaan budaya sekolah dengan karakter. Di SDN 2 Tukadmungga, nilai-nilai karakter sudah benar-benar dimutakhirkan dalam pelaksanaan pembelajaran muatan materi bahasa Indonesia. Materi pembelajaran yang selalu mengandung nilai karakter. Kegiatan pembelajaran sesuai dengan materi yang diajarkan meliputi nilai-nilai karakter yang digunakan dalam media pembelajaran. Kegiatan pembelajaran didasarkan pada RPP yang dikondisikan dengan situasi kelas. Di SDN 2 Tukadmungga dalam pembelajaran meliputi keterampilan menyimak, berbicara, membaca, dan menulis.

Guru melakukan evaluasi atau penilaian pendidikan karakter dari pertanyaan dan perilaku, yang kesemuanya untuk membuktikan nilai karakter dan pertanyaan yang masih berkaitan dengan materi pembelajaran pada kemampuan siswa. Evaluasi penilaian karakter juga dilakukan melalui penelitian. Tidak ada siswa yang lulus materi pembelajaran jika pendidikan karakter tidak lulus. Kelulusan pendidikan karakter mempengaruhi pelajaran bahasa Indonesia. Guru memasukkan penilaian praktis dalam RPP, yang selalu dikomunikasikan kepada wali kelas, kemudian mengkomunikasikan kepada orang tua hasil pendidikan karakter yang dilakukan. Berbeda dengan (Kanji et al., 2019) yang menilai pendidikan karakter lebih luas, yaitu melalui input, proses dan output pembelajaran. Perencanaan, pelaksanaan, penilaian pelaksanaan pendidikan karakter dalam pembelajaran dengan muatan bahasa Indonesia di SDN 2 Tukadmungga yang berbasis jaringan (online) melalui media online via WhatsApp, sebagai dampak dari pandemi Covid-19 telah dilakukan selama pandemi covid-19.

\section{Kesimpulan}

Pelaksanaan pendidikan karakter dalam pembelajaran dengan muatan bahasa Indonesia di SDN 2 Tukadmungga dilakukan melalui perencanaan, pelaksanaan, dan penilaian. Kegiatan guru bahasa Indonesia di SDN 2 Tukadmungga dalam perencanaan pembelajaran menambah nilai karakter yang ingin dicapai dalam RPP dan RPP untuk masing-masing kompetensi dasar. Pada tahap perencanaan, guru memilih nilai karakter 
yang disesuaikan dengan metode, materi, media, strategi, dan situasi pembelajaran. Penilaian pembelajaran bahasa Indonesia meliputi penilaian afektif. Pembelajaran bahasa Indonesia terdiri dari empat kompetensi, yaitu keterampilan menyimak, keterampilan berbicara, dan keterampilan berbicara.

\section{Daftar Pustaka}

Akhir, M. (2017). Pengembangan Materi Ajar Bahasa Indonesia Berbasis Karakter. Hlm.

Akhir, M. (2018). Integrasi Pendidikan Karakter Dalam Meningkatkan Keterampilan Menulis Mahasiswa Di Perguruan Tinggi. Prosiding Seminar Nasional Pendidikan, 1(1).

Azmi, N. (2017). Manajemen Pendidikan Karakter Siswa Man 1 Brebes dan MAN 2 Brebes. IAIN Purwokerto.

Bappenas. (2004). Visi Dan Arah Pembangunan Jangka Panjang (PJP) Tahun 2005-2025. Retrieved Maret, 23, 2017.

Kanji, H., Nursalam, N., Nawir, M., \& Suardi, S. (2019). Model integrasi pendidikan karakter dalam pembelajaran ilmu pengetahuan sosial di sekolah dasar. Jurnal Pendidikan Dasar Perkhasa: Jurnal Penelitian Pendidikan Dasar, 5(2), 104-115.

Malhotra, N. K. (2005). Riset Penelitian. Jakarta: Gramedia Pustaka Utama.

Saputri, S. (2013). Pelaksanaan Pendidikan Karakter di SD Kasihan Kabupaten Bantul. Hanata Widya, 2(6).

Silfia, M. (2018). penguatan pendidikan karakter dalam menghadapi era revolusi industri 4.0.

Suardi, S., Megawati, M., \& Kanji, H. (2018). Pendidikan Karakter di Sekolah (Studi Penyimpangan Siswa di Mts Muhammadiyah Tallo). JED (Journal of Etika Demokrasi), 3(1), 75-84. 